\title{
MATHEMATICAL LITERACY OF STUDENT COLLEGE FROM THEIR MATHEMATICAL LITERACY - SELF EFFICACY AND WORK STATUS
}

\author{
Eka Nurmala Sari Agustina \\ Mathematical Education Programm \\ STKIP PGRI Sidoarjo \\ Sidoarjo, Indonesia \\ eka.agustina.15@gmail.com
}

\author{
Dewi Sukriyah \\ Mathematical Education Programm \\ STKIP PGRI Sidoarjo \\ Sidoarjo, Indonesia \\ riyaitusakriyah@gmail.com
}

\begin{abstract}
This research is to see the different of pre-service teacher solving mathematical literacy problem by their mathematical literacy - self efficacy and their work status. This research included 16 student college that still at 7 th semester. They got questioner of mathematical literacy - self efficacy and three problems from PISA task 2012. The result of this research show that the work student college, has the average score of mathematical literacy - self efficacy lower than the not work student college. The high level of mathematical literacy - self efficacy is not show that the capacity of solving mathematical literacy always high too. The work status of student college gave more effect than the level of mathematical literacy - self efficacy when they solve mathematical literacy problems.
\end{abstract}

Keywords-Mathematical literacy - self efficacy, work status, Mathematical literacy

\section{INTRODUCTION}

Program for International Student Assessment (PISA) is an ongoing triennial survey from Organisation for Economic Cooperation and Development (OECD) that assesses reading literacy, mathematical literacy, and science literacy capability of 15 years old student near the end of compulsory education. [1]-[3]. Mathematical literacy is an individual's capacity to formulate, employ, and interpret mathematics in a variety of contexts, that includes reasoning mathematically and using mathematical concepts, procedures, facts and tools to describe, explain and predict phenomena, and it assists individuals to recognise the role that mathematics plays in the world and to make the well-founded judgments and decisions needed by constructive, engaged and reflective citizens.[4] The content of mathematical literacy are quantity, uncertainty, change and relationship, or shape and space. [5], [6]

PISA 2015 result show that mathematical literacy average score of Indonesian student was rising $17^{\text {th }}$ point from 369 to 386.[1]-[3]. Every time in PISA average rank of mathematical literacy, Indonesian mathematical literacy is always in lower rank. It can be important issue for the student college as the pre-service teacher to prepare student when they be a real teacher in the school. Based this situation, student college must have a good competence in mathematical literacy before they make their student familiar with mathematical literacy.

To solve mathematical literacy problem, everyone can involved their self efficacy to make themselves beliefs of the strategy they choose. Gulten [7] defined about mathematical literacy - self efficacy from Ozgen and Bindak's research that mathematical literacy - self efficacy is the belief and judgment in one's own capabilities when faced with mathematical challenges in school, work, and daily lives. There are some research about student' and adult's mathematical literacy - self efficacy, but that researches just seen the different of mathematical literacy - self efficacy based gender, the successes in mathematics, parent's educational education, school type, class level, math degree, the importance given to math class, and internet and $e$-book use while studying mathematics. (for example: [8], [7]). That research not including the mathematical literacy - self efficacy of student college that seen from their work status.

Every student college as pre-service teacher has different condition. There are the not work student college and the work student college. This condition can be the indication of the different mathematical capacity, but it can't be conclude that every work student college always has lower mathematical capacity. Purwandany's research shown that work student college had lower self regulation than not work student college [9]. That situation can be a factor about difference of their mathematical capacity, mathematical literacy - self efficacy, and the solving of mathematical literacy problems.

From some conditions above, not all student college just focus study (work student college), so there are some questions of this research, that are:

- How the different of work student college and not work student's college mathematical literacy - self efficacy? 
- Are the high and the low mathematical literacy - self efficacy of the student college in proportion to the high or the low of their mathematical literacy capacity?

- Is the student college mathematical literacy capacity has been influenced by their mathematical literacy self efficacy or their work status?

\section{METHOD}

\section{A. Research Subject}

This research includes 16 student college of STKIP PGRI Sidoarjo from 57 student that still at $7^{\text {th }}$ semester. There are 8 work student college and 8 not work student college. Their averages of age are $21-22$ years old.

\section{B. The Method of Data Collection}

There are two instruments that are 3 PISA problems of PISA 2012 Release Item [10] and Ozgen's and Bindak's questionnaire of mathematical literacy - self efficacy scale [11].

\section{Data Analyze}

This research use quantitative type. To see the level of mathematical literacy - self efficacy, it will be seeing with deviation standard that the lower score is 25 and the high score is 125 . The level of mathematical literacy - self efficacy is showed by TABLE I below.

TABLE I LEVEL OF MATHEMATICAL LITERACY - SELF EFFICACY

\begin{tabular}{|c|c|}
\hline Interval & Level \\
\hline ML-SESc ${ }^{\mathrm{a}}<\left(\overline{\boldsymbol{x}}-D S^{\mathrm{b}}\right)$ & $\begin{array}{c}\text { The Low Mathematical } \\
\text { Literacy - Self Efficacy } \\
\text { (Low ML-SE) }\end{array}$ \\
\hline$(\overline{\boldsymbol{x}}-D S) \leq$ ML-SESc $\leq(\overline{\boldsymbol{x}}+D S)$ & $\begin{array}{c}\text { The Medium } \\
\text { Mathematical Literacy - } \\
\text { Self Efficacy } \\
\text { (Medium ML-SE) }\end{array}$ \\
\hline ML-SESc $>(\overline{\boldsymbol{x}}+D S)$ & $\begin{array}{c}\text { The High Mathematical } \\
\text { Literacy - Self Efficacy } \\
\text { ( High ML-SE) }\end{array}$ \\
\hline \multicolumn{2}{|c}{ ML-SESc: Score of Mathematical Literacy- Self Efficacy } \\
b. DS: Deviation Standard
\end{tabular}

Mathematical literacy - self efficacy level will be described from all participants and their work status. Beside mathematical literacy - self efficacy level of all participants, in this research will be showed about the difference of worker and not work student college mathematical literacy - self efficacy and their mathematical literacy capacity. The different will be showed by $t$-test with error degree are 0.05 . The scoring of mathematical literacy problem are using the indicators below.

- Score 5: The answer is true, using logical reasoning, and using the true concepts and procedures.

- Score 4: The answer is true, using logical reasoning, but there are less wrong concepts and procedures.

- Score 3: The answer is true, using logical reasoning, but nothing calculate.

- Score 2: The answer is true, but there aren't logical reasoning.

- Score 1: The wrong answer

- Score 0: No Answer

\section{RESULT AND DisCUSSION}

\section{A. Mathematical Literacy - Self Efficacy of The Student College}

TABLE II and TABLE III below show about the average value and deviation standard of student college mathematical literacy and their level of mathematical literacy - self efficacy.

TABLE II VALUE OF MATHEMATICAL LITERACY - SELF EFFICACY

\begin{tabular}{|c|c|c|}
\hline N & $\overline{\boldsymbol{x}}$ & DS \\
\hline 16 & 75.31 & 10.25 \\
\hline TABLE III & LEVEL OF STUDENT COLLEGE MATHEMATICAL \\
& LITERACY -
\end{tabular}

\begin{tabular}{|c|c|c|c|}
\hline Interval & Category & Sum & $\begin{array}{c}\text { Percentage } \\
(\%)\end{array}$ \\
\hline ML-SESc $<65.06$ & $\begin{array}{c}\text { Low ML- } \\
\text { SE }\end{array}$ & 3 & 18.75 \\
\hline $65.06 \leq$ ML-SESc $\leq 85.56$ & $\begin{array}{c}\text { Medium } \\
\text { ML-SE }\end{array}$ & 11 & 68.75 \\
\hline ML-SESc $>85.56$ & $\begin{array}{c}\text { High } \\
\text { ML-SE }\end{array}$ & 2 & 12.5 \\
\hline
\end{tabular}

TABLE III give us information that $18.75 \%$ of student college was included in low level of mathematical literacy self efficacy, $68.75 \%$ of student college was included in medium level of mathematical literacy - self efficacy, and $12.5 \%$ of student college was included in high level of mathematical literacy - self efficacy. But from TABLE II, we can see that all sample was included in medium level of mathematical literacy - self efficacy.

Beside information about level of mathematical literacy, this research was giving us information of student college mathematical literacy based on work status. It will be shown in TABLE IV.

TABLE IV

T-TEST OF STUDENT COLLEGE MATHEMATICAL LITERACY SELF EFFICACY BASED ON WORK STSTUS

\begin{tabular}{|c|c|c|c|c|c|}
\hline Work Status & $\mathbf{N}$ & $\overline{\boldsymbol{x}}$ & DS & t-result & t-table \\
\hline $\begin{array}{c}\text { Work student } \\
\text { college } \\
(\text { Wsc) }\end{array}$ & 8 & 71.13 & 6.20 & & \\
\hline $\begin{array}{c}\text { Non work student } \\
\text { college } \\
\text { (NWsc) }\end{array}$ & 8 & 79.5 & 12.11 & 0.05 & 1.75 \\
\hline
\end{tabular}

From $t$-test result in TABLE IV above, give us information that $t$-result score was lower than $t$-table score. It show that there is significant different between Wsc and NWsc mathematical literacy - self efficacy. NWsc got higher average score of mathematical literacy - self efficacy than Wsc mathematical literacy - self efficacy. It could be happened because Wsc doesn't have good self regulated as Pusrwandany's research. He said that Wsc had lower self regulated than NWsc [9]. It can be effect of the time Wsc study about mathematical literacy, so they get lower score mathematical literacy - self efficacy than NWsc. 


\section{B. The Result of student college mathematical literacy score}

The result of student college mathematical literacy score can be seen in TABLE V. In TABLE V too, we can see the correlation of mathematical literacy score, mathematical literacy - self efficacy level, and work status of the student college.

TABLE V THE STUDENT COLLEGE MATHEMATICAL LITERACY RESULT

\begin{tabular}{|c|c|c|c|c|c|c|}
\hline \multirow[t]{2}{*}{$\begin{array}{l}\text { Subject } \\
\text { Initial }\end{array}$} & \multirow[t]{2}{*}{ Category } & \multirow[t]{2}{*}{$\begin{array}{l}\text { Work } \\
\text { Status }\end{array}$} & \multicolumn{3}{|c|}{$\begin{array}{c}\text { Number of } \\
\text { Problem }\end{array}$} & \multirow[t]{2}{*}{ Total } \\
\hline & & & 1 & 2 & 3 & \\
\hline $\mathrm{NI}$ & $\begin{array}{c}\text { Low } \\
\text { ML-SE }\end{array}$ & Not Work & 5 & 3 & 3 & 11 \\
\hline $\mathrm{M}$ & $\begin{array}{c}\text { Low ML- } \\
\text { SE }\end{array}$ & Work & 5 & 4 & 2 & 11 \\
\hline $\mathrm{H}$ & $\begin{array}{c}\text { Low ML- } \\
\text { SE }\end{array}$ & Not Work & 5 & 5 & 4 & 14 \\
\hline $\mathrm{MZ}$ & $\begin{array}{l}\text { Medium } \\
\text { ML-SE }\end{array}$ & Not Work & 5 & 1 & 5 & 11 \\
\hline $\mathrm{MH}$ & $\begin{array}{l}\text { Medium } \\
\text { ML-SE }\end{array}$ & Not Work & 5 & 5 & 5 & 15 \\
\hline AR & $\begin{array}{l}\text { Medium } \\
\text { ML-SE }\end{array}$ & Not Work & 5 & 4 & 1 & 10 \\
\hline $\mathrm{CW}$ & $\begin{array}{l}\text { Medium } \\
\text { ML-SE }\end{array}$ & Not Work & 4 & 1 & 2 & 7 \\
\hline AI & $\begin{array}{l}\text { Medium } \\
\text { ML-SE }\end{array}$ & Work & 5 & 3 & 2 & 10 \\
\hline $\mathrm{D}$ & $\begin{array}{l}\text { Medium } \\
\text { ML-SE }\end{array}$ & Not Work & 5 & 5 & 2 & 12 \\
\hline AS & $\begin{array}{l}\text { Medium } \\
\text { ML-SE }\end{array}$ & Work & 5 & 4 & 1 & 10 \\
\hline $\mathrm{PN}$ & $\begin{array}{l}\text { Medium } \\
\text { ML-SE }\end{array}$ & Work & 5 & 2 & 2 & 9 \\
\hline I & $\begin{array}{l}\text { Medium } \\
\text { ML-SE }\end{array}$ & Not Work & 5 & 5 & 1 & 11 \\
\hline $\mathrm{N}$ & $\begin{array}{l}\text { Medium } \\
\text { ML-SE }\end{array}$ & Work & 5 & 2 & 2 & 9 \\
\hline SL & $\begin{array}{l}\text { Medium } \\
\text { ML-SE }\end{array}$ & Work & 5 & 1 & 3 & 9 \\
\hline KA & $\begin{array}{c}\text { High } \\
\text { ML-SE }\end{array}$ & Work & 5 & 1 & 3 & 9 \\
\hline A & $\begin{array}{c}\text { High } \\
\text { ML-SE }\end{array}$ & Work & 5 & 5 & 4 & 14 \\
\hline
\end{tabular}

TABLE VI T-TEST RESULT OF STUDENT COLLEGE MATHEMATICAL CAPACITY BASED ON WORK STATUS

\begin{tabular}{|c|c|c|c|c|c|}
\hline $\begin{array}{c}\text { Work } \\
\text { Status }\end{array}$ & $\mathbf{N}$ & $\overline{\boldsymbol{x}}$ & $\mathbf{D S}$ & t-result & t-tabel \\
\cline { 1 - 4 } Wsc & 8 & 10.125 & 2.982 & 0.129 & \multirow{2}{*}{1.75} \\
\cline { 1 - 4 } NWs & 8 & 11.375 & 5.982 & & \\
\hline
\end{tabular}

TABLE $\mathrm{V}$ is giving us information that student college mathematical literacy - self efficacy doesn't have correlation with their mathematical literacy capacity. It was be shown by KA's and CW's score mathematical literacy and KA's and CW's level of mathematical literacy - self efficacy. KA was in high level of mathematical literacy - self efficacy and CW was in medium level of mathematical literacy - self efficacy but they got low score of mathematical literacy, actually CW's score was lowest. KA and CW isn't just one reason that the mathematical literacy - self efficacy doesn't have correlation with the mathematical literacy capacity. There is $\mathrm{H}$ that his mathematical literacy score was high but he was included in low level of mathematical literacy - self efficacy. From TABLE V too we can see that work status has influence with mathematical literacy capacity than mathematical literacy self efficacy. The information of TABLE VI, support us to conclude that mathematical literacy was influenced by work status. TABLE VI give us information that $t$-result was lower than $t$-table. It show that there is significant different of Wsc and NWsc mathematical literacy capacity. Wsc got lower average score of mathematical literacy than Wsc.

\section{CONCLUSION}

There are 3 conclusions of this research such as:

- The work student college has lower mathematical literacy - self efficacy than the not work student college. So they must be increasing their self efficacy when they solve mathematical literacy problem.

- Mathematical literacy - self efficacy is not the one factor that mathematical literacy capacity will be good if Mathematical literacy - self efficacy is good.

- Mathematical literacy capacity of the non work student college is better than mathematical literacy capacity of the work student college.

\section{REFERENCES}

[1] Kemendikbud, "Kementerian Pendidikan dan Kebudayaan » Republik Indonesia," 2016 [Online]. Available: https://www.kemdikbud.go.id/main/blog/2016/12/peringkatdancapaian-pisa-indonesia-mengalami-peningkatan. [Accessed: 02Oct2017].

[2] OECD, "PROGRAMME FOR INTERNATIONAL STUDENT ASSESSMENT (PISA) RESULT FROM PISA 2015 'INDONESIA,", pp. $1-8,2016$.

[3] J. Cleary, S. Breen, and A. O'Shea, "Mathematical literacy and selfefficacy of first year third level student," MSOR Connect., vol. 10 , no. 2, pp. 41-44, 2010 .

[4] OECD, PISA 2012 Assessment and Analytical Framework: Mathematics, Reading, Science, Problem Solving and Financial Literacy. OECD Publishing, 2013.

[5] J. De Lange, "Mathematical literacy for living from OECD-PISA perspective," Tsukuba J. Educ. Study Math., vol. 25, pp. 13-35, 2006. [6] K. Stacey, "The PISA view of mathematical literacy in Indonesia," Indones. Math. Soc. J. Math. Educ., vol. 2, no. 2, pp. 95-126, 2011.

[7] D. Ç. Gülten, "Distance education student' self -efficacy levels of mathematical literacy," Educ. Res. Rev., vol. 8, no. 14, pp. 1137-1143, 2013.

[8] K. Özgen and R. B. İ. Ndak, "Determination of Self-Efficcacy Beliefs of High School Student towards Math Literacy," vol. 11, no. 2, pp. 1085-1090, 2011.

[9] A. Purwandany, "PERBEDAAN TINGKAT REGULASI DIRI MAHASISWA YANG BEKERJA PARUH WAKTU DAN MAHASISWA YANG TIDAK BEKERJA PADA PRODI PENDIDIKAN MATEMATIKA ANGKATAN 2008 2009 UNIVERSITAS MUHAMMADIYAH GRESIK," $J$. Psikosains, vol. 4, no. 1, pp. 45-58, 2009. [10] OECD, "PISA 2012 Released Item," 2012, pp. 1-16.

[11] K. Özgen and R. Bindak, "Matematik Okuryazarlığı Öz-Yeterlik Ölçeğinin Geliştirilmesi,” no. 2, pp. 517-528, 2008. 